\title{
Analysis of financial and economic feasibility of the use of vinasse for electricity generation in Brazil
}

\author{
Geraldo Jose Ferraresi de Araujo ${ }^{1}$ \\ Sonia Valle Walter Borges de Oliveira ${ }^{1}$
}

${ }^{1}$ Universidade de SÃo Paulo (USP) / Faculdade de Economia, Administração e Contabilidade de Ribeirão Preto, RIBEIRÃO PRETO - SP, BRAZIL

\begin{abstract}
In view of the growing importance of distributed generation, the pluralization of the energy matrix close to large consumption centers has become necessary. In this sense, the energy sector can contribute to electricity generation using waste products such as vinasse, the most relevant in terms of volume and polluting capacity. The general objective of this article is to analyze the economic feasibility of using vinasse for electricity generation, and as a specific objective, to identify the viable price range of MWh in free and regulated energy environments and the productive capacity of plants for this type of investment. The methodology used was quantitative research, based on the cost structure of a biodigester IC internal combustion engine with 38\% yield and vinasse logistics according to the production capacity of autonomous plants of $100 \mathrm{~m}^{3}, 1,000 \mathrm{~m}^{3}$ and 3,000 $\mathrm{m}^{3}$ ethanol/day for scenarios with and without tax exemptions for a price range between US\$26.04 and US\$ 130.20/MWh. The analysis shows that the use of vinasse for electricity generation is restricted to medium and large producers. Furthermore, the price of MWh is more relevant than the tax exemption for the feasibility of this type of project. This corroborates the constant requests from the sugar-energy sector to hold exclusive electricity auctions for biomass, given its cost structure and its social, economic, and environmental externalities.
\end{abstract}

Keywords: Vinasse. Electricity. Financial and economic feasibility. Electricity market. Public auctions of electricity.

\section{Análise de viabilidade econômica financeira do uso de vinhaça para geração de eletricidade no Brasil}

\section{Resumo}

Ante a crescente importância da geração distribuída, a pluralização da matriz energética próxima aos grandes centros de consumo tornou-se necessário. Nesse sentido, o setor de sucro energético pode contribuir para a geração de eletricidade utilizando resíduos como vinhaça, o mais relevante em volume e capacidade poluidora. Logo, objetivo geral deste artigo é analisar a viabilidade econômico do uso de vinhaça para geração de eletricidade, como objetivo específico, identificar a faixa de preço viável do MWh nos ambientes livre e regulado de energia e a capacidade produtiva das plantas para esse tipo de investimento. A metodologia utilizada foi a pesquisa quantitativa, com base na estrutura de custo de biodigestor IC, motor de combustão interna com 38\% de rendimento e logística de vinhaça em função da capacidade de produção de usina autônomas em $100 \mathrm{~m}^{3}, 1.000 \mathrm{~m}^{3}$ e $3.000 \mathrm{~m}^{3}$ etanol / dia para cenários com e sem isenção de impostos para uma faixa de preço entre US\$26,04 a US\$130,20 / MWh. A análise permite observar que o uso de vinhaça para geração de eletricidade está restrito a produtores de médio e grande porte. Outrossim, o preço do MWh é mais relevante que a isenção fiscal para viabilidade deste tipo de projeto. Isso corrobora os constantes pedidos do setor sucroenergetico para realização leilões de eletricidade exclusivos para biomassa, dado sua estrutura de custos e suas as externalidades sociais, econômicas e ambientais.

Palavras-chave: Vinhaça. Eletricidade. Viabilidade econômica financeira. Mercado de eletricidade. Leilões públicos de eletricidade.

\section{Análisis de viabilidad económico-financiera del uso de vinaza para generación de electricidad en Brasil}

\section{Resumen}

En vista de la creciente importancia de la generación distribuida, la pluralización de la matriz energética cerca de los grandes centros de consumo se ha vuelto necesaria. En este sentido, el sector azucarero-energético puede contribuir a la generación de electricidad utilizando residuos como la vinaza, el más relevante en términos de volumen y capacidad contaminante. Por lo tanto, el objetivo general de este artículo es analizar la viabilidad económica del uso de vinaza para la generación de electricidad, como un objetivo específico, para identificar el rango de precio viable de MWh en entornos de energía libres y regulados y la capacidad productiva de las plantas para este tipo de inversión. La metodología utilizada fue la investigación cuantitativa, basada en la estructura de costos de biodigestores IC, motor de combustión interna con 38\% de rendimiento y logística de vinaza de acuerdo con la capacidad de producción de la planta autónoma en $100 \mathrm{~m}^{3}, 1,000 \mathrm{~m}^{3}$ y 3,000 $\mathrm{m}^{3}$ de etanol/día para escenarios con y sin exención de impuestos para un rango de precios entre US\$26,04 a US\$130,20/MWh. El análisis muestra que el uso de vinaza para la generación de electricidad está restringido a productores medianos y grandes. Además, el precio del MWh es más relevante que la exención de impuestos para la viabilidad de este tipo de proyecto. Esto corrobora las constantes solicitudes del sector azucarero-energético para realizar subastas exclusivas de electricidad para biomasa, dada su estructura de costos y sus externalidades sociales, económicas y ambientales.

Palabras clave: Vinaza. Electricidad. Viabilidad económica y financiera. Mercado de electricidad. Subastas públicas de electricidad. 


\section{INTRODUCTION}

Electricity is a fundamental requirement for a nation's economic and social development, and having a sufficient volume of energy that is reliable and appropriate to the needs of this development is a critical factor for progress. Moreover, it should be economically competitive and not harmful to the environment.

Santos, Barros and Tiago Filho (2016) state that there is a strong relationship between energy consumption and social development in Brazil and throughout the world. Therefore, having a diversified, clean, low-cost and structured energy matrix is essential for economic and social development that respects the environment. Although Brazil has a varied and relatively clean energy matrix compared with other nations, it has one of the most expensive costs per $\mathrm{kWh}$ in the world.

According to Sugimoto (2014), regardless of the serious situation caused by the lack of rainfall in the country's southeastern region in the summers of 2013/2014 and 2014/2015, there were also a number of untimely measures that led to energy insecurity and a reduction in investment, along with an excessive increase in the use of thermoelectric power. As a result, electricity production costs rose and Brazilian industry lost competitiveness.

The crisis in the Brazilian electricity sector arose due to a combination of three major problems: political interference, a lack of rainfall and delays in investments. According to Rodrigues (2014), the deficit in the sector may reach more than US\$ 7.29 billion.

In order to change this situation, which is undermining the country's economic growth and social well-being, energy policies should overcome the challenges and achieve the following results: making the existing systems efficient by eliminating waste and maximizing the performance of conversion processes; creating integrated energy planning processes; including states and civil society in decision-making; and democratizing the process of formulating and implementing energy policies. Therefore, overcoming energy challenges and promoting Brazil's development are connected and should be discussed within a broad context.

Regarding electricity transmission, according to Moreira and Millikan (2012), one-fifth of the energy produced in the country is wasted during its transmission to consumption centers. In 2008, losses in electricity transmission and distribution in Brazil totaled $16 \%$ of the total energy produced by the generation system. The country's energy matrix, based on hydroelectric power plants, requires extensive lines of transmission to bring electricity to consumers. Great losses imply higher energy costs, which directly affect economic growth. According to the Energy Research Company (EPE, 2014), the variation of adjustments and losses in 2014 was 93,174 GWh.

Especially in regard to energy efficiency and planning, a more intensive use of renewable energy sources near consumption centers appears to be one of several items that are needed to overcome the electricity crisis in line with sustainable development.

As mentioned by Dantas Filho (2009), electricity generation from sugarcane has extreme environmental, economic and social relevance in view of the following considerations: its renewable nature; the sale of surplus energy to the national electricity system; the generation of jobs; the reduction of greenhouse gas emissions and transmission losses; and the reliability of the energy supply, especially during the dry season, as well as rapid deployment projects. The biomass generated by the sugar and alcohol industry may contribute significantly to the strengthening of the Brazilian energy matrix.

Electricity generation by using sugarcane biomass represents an important source of income for the sector. Among the various residues of the sugarcane-based energy industry, which consist of bagasse, straw, filter cake and vinasse, the latter stands out in terms of its production volume and pollutant load, and also its capacity for biogas generation when treated using biodigesters.

In this sense, vinasse has attracted the attention of researchers and the main scientific journals in the energy area. Moreda (2016) analyzed the potential for biogas and electricity generation from organic residues in Uruguay and obtained a result of 2.6 million $\mathrm{m}^{3}$ /year, equivalent to an electricity production of $8.9 \mathrm{GWh} /$ year. Bundhoo, Mauthoor and Mohee (2016) estimated the potential for electricity generation from vinasse to be $268 \mathrm{TJ} /$ year in Mauritius and suggested the digestion of this residue as an alternative to reduce the island's heavy dependence on fossil fuels. According to Moraes, Junqueira, Pavanello et al. (2014), the use of vinasse biogas for electricity generation in stationary internal combustion engines could have generated US\$ 85 million in carbon credits for Brazil’s revenue in 2009. 
Nogueira, Souza, Micuanski et al. (2015) studied the use of this residue to generate electricity in power plants with a $1 \mathrm{MW}$ generation capacity, finding the economic feasibility for the three production scenarios evaluated $(7,236$ production hours/year; 5,000 production hours/year; and from 4,000 to 8,000 production hours/year). Only Scenario 1 was not feasible at a price of US\$59.83/MWh.

This article contributes to the scientific literature due to its approach in utilizing vinasse to generate electricity, based on the cost structure of an internal circulation (IC) biodigester internal combustion engine with a $38 \%$ yield and vinasse logistics according to a production capacity of autonomous plants of $100 \mathrm{~m}^{3}, 1,000 \mathrm{~m}^{3}$ and 3,000 $\mathrm{m}^{3}$ ethanol / day for scenarios with and without tax exemptions (5.93\% of gross sales) for a price range between US\$26.04 and US\$130.20/MWh, which is the basis for the calculations of electricity contracts in Brazil under a free environment or a regulated one.

Based on the mentioned articles, this study has the overall objective of analyzing the economic-financial viability of using vinasse to generate electricity. The specific objective, in turn, is to identify the minimum price range per MWh in free electricity markets and regulated ones in Brazil and the productive capacity of plants which are attractive for this type of investment, which also leads to a discussion of the local generation of electricity, or in other words, generation distributed by states that produce ethanol.

\section{CLEAN DEVELOPMENT MECHANISM (CDM) AND BIOELECTRICITY IN BRAZIL: ITS IMPORTANCE, POLICIES AND CHALLENGES}

During the Third Conference of the Parties (COP 3) in 1997, the creation of the Kyoto Protocol was announced which went into effect in February 2005, with its first commitment period being 2008-2012. At the end of this period during COP 18, which took place in Doha in 2012, the participating countries announced the Doha Amendment to the Kyoto Protocol, deferring the second period of commitment to 2013-2020, and establishing a plan to negotiate a new post-2020 climate accord during COP 21, which was held in Paris in 2015 and has become known as the Paris Accord.

The Paris Accord assumes targets to limit greenhouse gas emissions, and unlike the Kyoto Protocol, developed and developing countries have established mandatory targets to reduce greenhouse gas emissions and support sustainable development (Art. 6, § 4, paragraph a). In this sense, it may be observed that the Paris Acord follows CDM objectives, integrating the reduction of greenhouse gas emissions with the promotion of sustainable development (LAZARO and GREMAUD, 2017).

The CDM, created with Kyoto Protocol Article 12, and reaffirmed in Paris Accord Article 6, determines that CDM is a two-way instrument, helping industrialized countries to reduce their greenhouse gas emissions and promoting sustainable development in developing countries. In this sense, CDM projects in Brazil mainly contemplate renewable energy generation sectors such as hydroelectricity, wind and biomass which constitute $61 \%$ of the projects (MORI-CLEMENT and BEDNAR-FRIEDL, 2019).

To the Ministry of Mining and Energy (MME, 2017), energy is a long-term form of investment. Soon, energy policy and planning should be capable of making relevant choices for sustainable development. Therefore, it is necessary to reflect on a strategic policy for the state which will be immune to governmental changes and will bring security to investors, businessmen, and consumers. In this sense, we can highlight the following strategic policies: the National System of Conservation Units Law (Law 9,985/2000); New Energy Auctions (Law 10,848/2004); the National Policy on Climate Change (Law 12,187/2009); and the New Forest Code (Law 12,651/2012).

In addition, in terms of Brazil's accord (2020), the National Climate Change Fund has a budget of approximately R\$1.07 billion for the period between 2020-2023, with the objective of fulfilling the targets established by the Paris Accord in terms of reducing greenhouse gas emissions by $37 \%$ below 2005 levels by 2025, and by $43 \%$ by 2030, based on the following measures: combatting deforestation; increasing the participation of bioenergy by $18 \%$ by 2030 and reaching a total of $45 \%$ renewable energy within the energy matrix by 2030 (OLIVEIRA, GURGEL and TONRY, 2019).

In this sense, biomass can contribute to achieving the goals established by the Paris Accord. The utilization of residues such as bagasse, straw and vinasse as a source of energy to Goldemberg and Lucon (2007), can create 150 times more employment 
per unit of energy than petroleum. In addition, according to Bernal, Santos, Silva et al. (2017), sugarcane is one of the most promising sources for bioenergy generation in the Brazilian context, since sugarcane is harvested in the dry season, complementing the electricity generation from hydroelectric power plants, which are the country's main electricity source and account for $64 \%$ of all electric power generation.

However, even with the above-mentioned bioelectricity benefits between 2014 and 2016, the electricity supply crisis in Brazil led to a need to contract a relevant amount of thermoelectric power driven by fuel oil to supply electricity to the National Interconnected System. To Lopes (2013), although these plants have compatible technical and economic characteristics to operate on the outskirts of the system and act as backups, they are costly when they operate as the system's base. Moreover, they have intense greenhouse gas emissions and high operating costs since the raw materials are generally imported.

According to Castro and Dantas (2008), after the reserve energy auction held in 2008 exclusively for biomass enterprises, it was observed that this fuel has been losing competitiveness in auctions, mainly in comparison to wind energy, which shows that auctions are seeking rates which are much higher than those involved in including alternative sources of energy.

This alleged lack of competitiveness is the result of a methodology of conducting auctions that does not correctly obtain the benefits of bioelectricity for the Brazilian electric system, given additional electricity that it provides to the national hydroelectric park. Sugarcane-based bioelectricity is a source of energy that contributes to the security of Brazil's electric energy supply, but it has not been properly valued at auctions. Besides, many bioelectricity generation power plants are located far from the substations that can transmit the produced electricity. Thus, access to the electrical matrix becomes a barrier to the incorporation of new bioelectricity generation projects (CASTRO and DANTAS, 2008).

In this sense, to Lopes (2013), sugarcane-based bioelectricity needs to become cost competitive in order to be successful in auctions of the Regulated Contracting Environment (RCE). Even though there are trade potential opportunities in the Free Contracting Environment (FCE), RCE auctions have appeared to the sugarcane-based energy sector as a long-term alternative that offers long-term revenue guarantees. These guarantees have often been offered for the purpose of obtaining financing for the construction of thermoelectric projects.

On the other hand, the FCE appears to be an option to trade electricity surpluses, since buyer and supplier companies establish commercial agreements that are often more advantageous than those established in the RCE (LOPES, 2013).

To Araujo (2017), even with the methodological distortions of the RCE auctions and the contracting of thermoelectric power plants during the electricity supply crisis between 2014 and 2016, sugarcane, the main exponent of renewable energy types, cannot be restricted to the production of ethanol and bagasse burning. All of its residues, such as straw and vinasse, can be used to produce electricity, as well as carbon credits in the CDM.

\section{VINASSE: OPPORTUNITIES AND CHALLENGES}

Vinasse is one of the main residues of ethanol production, and it can be reused by co-generation for electricity production due to its high level of organic content. This residue, according to Hoarau (2018), is an acidic (pH 3.5-5) aqueous residue generated by the distillation of alcoholic must during the ethanol production process, with a high level of organic content represented by high chemical oxygen demand (COD) (up to $140 \mathrm{~g} / \mathrm{L}$ ), presenting a dark brown color due to the presence of melanoidin and an unpleasant odor. It contains nutrients such as nitrogen (up to $4.2 \mathrm{~g} / \mathrm{I}$ ), phosphorus (up to $3.0 \mathrm{~g} / \mathrm{l}$ ) and potassium (up to $17.5 \mathrm{~g} / \mathrm{l}$ ).

To Moraes, Zaiat and Bonomi (2015), vinasse is an effluent of high polluting potential, containing high levels of organic compounds and nutrients (mainly potassium, but also nitrogen and phosphorus). It is derived from the ethanol distillation step (with columns at a temperature range of 85-90 degrees Celsius), and the presence of melanoidin and a high level of organic acid content leading to its brownish color and low $\mathrm{pH}$. 
As stated by Christofoletti, Escher, Correia et al. (2013), vinasse may also contain heavy metals and organic xenobiotic pollutants, such as phenol, methylene chloride, chloroform and pentachlorophenol, as well as potassium, organic matter and nitrogen. Heavy metals $(\mathrm{Cu}, \mathrm{Zn}, \mathrm{Ni}, \mathrm{Mn}, \mathrm{Pb})$ generally appear in insignificant concentrations and most often they are below the detection limits of the atomic absorption spectrophotometer ( $5 \mathrm{mg} / \mathrm{kg}$ for $\mathrm{Cu}, \mathrm{Zn}, \mathrm{Ni}, \mathrm{Pb}$ and $10 \mathrm{mg} / \mathrm{kg}$ for $\mathrm{Mn}$ ). Table 1 displays the physical-chemical characteristics of vinasse in different raw materials.

Table 1

Physical-Chemical Characteristics of Vinasse in Various Raw Materials

\begin{tabular}{ccccc}
\hline Feedstock & Sugarcane molasses & Sugarcane juice & Corn & Beet molasses \\
\hline $\mathrm{pH}$ & $3.9-4.3$ & 4.04 & $3.3-4$ & 5.35 \\
$\mathrm{COD}(\mathrm{g} / \mathrm{L})$ & $104-134.4$ & 30.4 & $59.4-64.5$ & 91.1 \\
$\mathrm{BOD}(\mathrm{g} / \mathrm{L})$ & $46.1-96$ & 16.7 & $26.9-43.1$ & 44.9 \\
$\mathrm{~N}(\mathrm{~g} / \mathrm{L})$ & $1.66-4.2$ & 0.63 & $0.546-0.755$ & 3.57 \\
$\mathrm{~S}(\mathrm{~g} / \mathrm{L})$ & $3.24-3.42$ & 1.35 & 2.99 & 3.71 \\
$\mathrm{P}(\mathrm{g} / \mathrm{L})$ & $0.22-3.03$ & 0.13 & $0.228-1.170$ & 0.16 \\
$\mathrm{~K}(\mathrm{~g} / \mathrm{L})$ & $9.6-17.47$ & 1.95 & n.d. & 10 \\
\hline
\end{tabular}

Source: Hoarau (2018) and Wilkie, Riedesel and Owens (2000). n.d.: no data.

Koyama, Araújo Júnior, Zaiat et al. (2016) list typical concentrations of heavy metals in vinasse from sugarcane, showing that when these contaminants are present, they are always in concentrations below $0.5 \mathrm{mg} / \mathrm{l}$. Heavy metals concentrations found in sugarcane vinasse are summarized in table 2.

Table 2

Heavy Metals Found in Sugarcane Vinasse

\begin{tabular}{cc}
\hline Element & Concentration $(\mathrm{mg} / \mathrm{l})$ \\
\hline Barium & 0.41 \\
Chromium & 0.04 \\
Copper & 0.35 \\
Mercury & 0.0019 \\
Molybdenum & 0.008 \\
Nickel & 0.03 \\
Zinc & 1.66 \\
\hline
\end{tabular}

Source: Hoarau (2018).

According to the Sugarcane Industry Association (UNICA, 2014), Brazilian production in the 2013/2014 harvest was around 25.04 billion liters of ethanol, and the vinasse production in this harvest was at least of 250 billion liters, a very worrying volume.

The normative instruments and published legislation aim not only to mitigate the disposal of vinasse in soils and water bodies, but also to encourage new applications for this residue, promoting economic and social development from its reuse, in keeping with environmental preservation as well as Life Cycle Thinking (LCT), which according to Kiss (2018), seeks to reduce the consumption of natural resources and greenhouse gases and optimize socioeconomic performance.

Based on available technologies for the reuse of vinasse, Oliveira (2011) enumerates alternatives aligned in terms of sustainable development as well as LCT. Among these we can mention: anaerobic digestion for the production of methane; fertigation; incineration for reusing ash in agriculture; evaporation for animal feed production; biodiesel production; fungus production; its use in construction materials and electricity generation. 
Regarding electricity generation specifically, according to the Moraes, Junqueira, Pavanello et al. (2014) it appears to be an alternative, because it reduces pollution potential and maintains fertigation characteristics, normalizing the COD and $\mathrm{pH}$.

\section{METHODOLOGY}

This is a quantitative study which is designed to analyze the net present value (NPV), the internal rate of return (IRR), and the discounted payback of the use of vinasse for the generation of electricity.

At the time of this article's writing, there are no existing vinasse plants, so this study has used a simulation based on secondary sources collected from three governmental bodies: the National Petroleum Agency (ANP, 2017), whose data refers to the size of ethanol production plants; the National Electricity Agency (ANEEL, 2016), whose data is related to the auction prices for electricity within the regulated auction environment (ACR); and the Congress of Electricity Commercialization (2017), with data referring to the prices practiced in the free auction environment ( $A C L$ ).

As in Araujo, Oliveira and Oliveira (2019), the calculations were performed based on the use of an IC biodigester and a $38 \%$ yield internal combustion generator, as defined by Procknor (2009), and for various MWh price ranges as follows: US\$ 26.04 , US\$ 52.08, US\$ 78.125, US\$ 104.16 and US\$ 130.20, which encompass both the RCE and the FCE with the sale of carbon credits at US\$18.72/t CO 2 equivalent mitigated, following Investing (2017), and annual savings due to a lack of fines of US\$ 471.35, according to Simões, Sena and Campos (2004).

According to Poveda (2014) given a certain production of vinasse biodigested per day, $5 \%$ is distributed using the 2318 truck, with a tank of $15 \mathrm{~m}^{3} ; 24 \%$ through the Volvo road train truck, with two tanks of $30 \mathrm{~m}^{3}$ each, together with an MB OM 352 $160 \mathrm{CV}$ engine and EQ $9048140 \mathrm{~m}^{3} / \mathrm{h}$ pump for vinasse sprinkling, and 71\% is transported exclusively by an MB OM $352160 \mathrm{CV}$ engine and EQ $9048140 \mathrm{~m} / \mathrm{h}$ pump.

Table 3 presents the values pertaining to diesel consumption for each logistic modality, based on the transportation values of vinasse biodigested per day for each modality, together with the values referring to the average distance travelled per day for fertigation, average speed of the vehicle, time to load and unload the vinasse, the number of 2318-type and Volvo road train trucks necessary to transport vinasse, as well as the number of truckers, assuming three work shifts per day.

Table 3

Data Pertaining to the Transportation Modalities for Biodigested Vinasse

\begin{tabular}{|c|c|c|c|c|c|}
\hline $\begin{array}{c}\text { Transportation } \\
\text { and application } \\
\text { system }\end{array}$ & Machine & $\begin{array}{l}\text { Volume } \% \\
\text { of vinasse to } \\
\text { transport }\end{array}$ & $\begin{array}{l}\text { Average distance } \\
\text { travelled for } \\
\text { fertigation }(\mathrm{km})\end{array}$ & $\begin{array}{l}\text { Average speed } \\
\text { travelled by the } \\
\text { truck }(\mathrm{km} / \mathrm{h})\end{array}$ & $\begin{array}{l}\text { Average time } \\
\text { of application } \\
\text { and reloading of } \\
\text { vinasse (hours) }\end{array}$ \\
\hline $\begin{array}{l}\text { Truck applying } \\
\text { directly }\end{array}$ & $\begin{array}{l}2318 \text { truck with tank } \\
\text { of } 15 \mathrm{~m}^{3}\end{array}$ & $5 \%$ & 7.00 & 35 & 0.3 \\
\hline $\begin{array}{l}\text { Truck with } \\
\text { sprinkler } \\
\text { combined with } \\
\text { motor pump }\end{array}$ & $\begin{array}{l}\text { Volvo road train truck } \\
\text { with two tanks of } 30 \\
\mathrm{~m}^{3} \text { each and motor } \\
\text { pump }\end{array}$ & $24 \%$ & 12.00 & 20 & 1.2 \\
\hline $\begin{array}{l}\text { Motor pump in } \\
\text { channel with } \\
\text { direct or roll } \\
\text { mounting }\end{array}$ & $\begin{array}{l}\text { MB OM } 352160 \text { CV } \\
\text { engine and EQ } 9048 \\
140 \mathrm{~m}^{3} / \mathrm{h} \text { pump }\end{array}$ & $71 \%$ & 63.00 & ND & ND \\
\hline
\end{tabular}

Source: Adapted from Poveda (2014). 
With regard to costs, the monthly driver's cost plus labor and social charges on wages is US\$1,277.31 per driver; fuel consumption per crop- 2318 truck, Volvo truck and MB OM 352 engine and EQ 9048 pump (liters), cost of fuel consumption per crop - truck 2318, truck Volvo road train and engine OM 352 and pump EQ 9048 (US\$) and the cost of depreciation per harvest of 2328 and Volvo truck fleet (US\$) is given as US\$1.562,50 according to Silva, Rios, Fraga et al. (2015) and the price of diesel is US\$ 0.87 according to Fuel prices (PREÇO DOS COMBUSTíVEIS, 2017).

Two scenarios were considered, namely: with tax exemptions, and without tax exemptions, that is, with taxes on electricity sales (Social Integration Program (PIS), Social Contribution on Net Income (CSLL), Corporate Income Tax (IRPJ), and the Social Security Financing Contribution (COFINS) of 5.93\% of gross revenue, as defined by Nogueira, Souza, Micuanski et al. (2015).

Both the aforementioned scenarios were elaborated for autonomous plants according to Moraes, Junqueira, Pavanello et al. (2014) that is, plants with exclusive ethanol production, with productive capacity of $100 \mathrm{~m}^{3}$ ethanol/day, 1,000 $\mathrm{m}^{3}$ ethanol/day, and $3,000 \mathrm{~m}^{3}$ ethanol/day, presenting COD vinasse of around $21 \mathrm{~kg} / \mathrm{m}^{3}, 4,800$ hours of harvest, and a minimum rate of attractiveness of $10 \%$ for a 20 -year horizon.

\section{RESULTS}

\section{Analysis of the internal rate of return}

Based on this result, the project is defined if the IRR is greater than the minimum return required. The advantages of using the IRR, as it is closely related to the NPV, corroborates the convergent investment decision.

The IRR for the ethanol production range considered in this study can be seen in both Table 4 and Graph 1 .

Table 4

Internal Rate of Return for the Sale of Electricity from Vinasse

\begin{tabular}{|c|c|c|c|c|c|c|}
\hline \multirow{2}{*}{$\begin{array}{l}\text { MWh price } \\
\text { (US\$) }\end{array}$} & \multicolumn{2}{|c|}{$\begin{array}{c}\text { Production of } 100 \mathrm{~m}^{3} \\
\text { ethanol/day }\end{array}$} & \multicolumn{2}{|c|}{$\begin{array}{c}\text { Production of } 1,000 \mathrm{~m}^{3} \\
\text { ethanol/day }\end{array}$} & \multicolumn{2}{|c|}{$\begin{array}{c}\text { Production of } 3,000 \mathrm{~m}^{3} \\
\text { ethanol/day }\end{array}$} \\
\hline & $\begin{array}{l}\text { IRR with tax } \\
\text { exemption }\end{array}$ & $\begin{array}{l}\text { IRR without } \\
\text { tax exemption }\end{array}$ & $\begin{array}{l}\text { IRR with tax } \\
\text { exemption }\end{array}$ & $\begin{array}{l}\text { IRR without } \\
\text { tax exemption }\end{array}$ & $\begin{array}{l}\text { IRR with tax } \\
\text { exemption }\end{array}$ & $\begin{array}{l}\text { IRR without } \\
\text { tax exemption }\end{array}$ \\
\hline 26.04 & ND & ND & $-8 \%$ & $-9 \%$ & $-7 \%$ & $-9 \%$ \\
\hline 52.08 & $-2 \%$ & $-3 \%$ & $7 \%$ & $6 \%$ & $7 \%$ & $6 \%$ \\
\hline 78.12 & $6 \%$ & $5 \%$ & $16 \%$ & $14 \%$ & $16 \%$ & $15 \%$ \\
\hline 104.16 & $12 \%$ & $11 \%$ & $23 \%$ & $22 \%$ & $24 \%$ & $22 \%$ \\
\hline 130.20 & $17 \%$ & $16 \%$ & $31 \%$ & $29 \%$ & $32 \%$ & $29 \%$ \\
\hline
\end{tabular}

Source: Elaborated by the authors. 


\section{Graph 1}

Internal Rate of Return for the Sale of Electricity from Vinasse

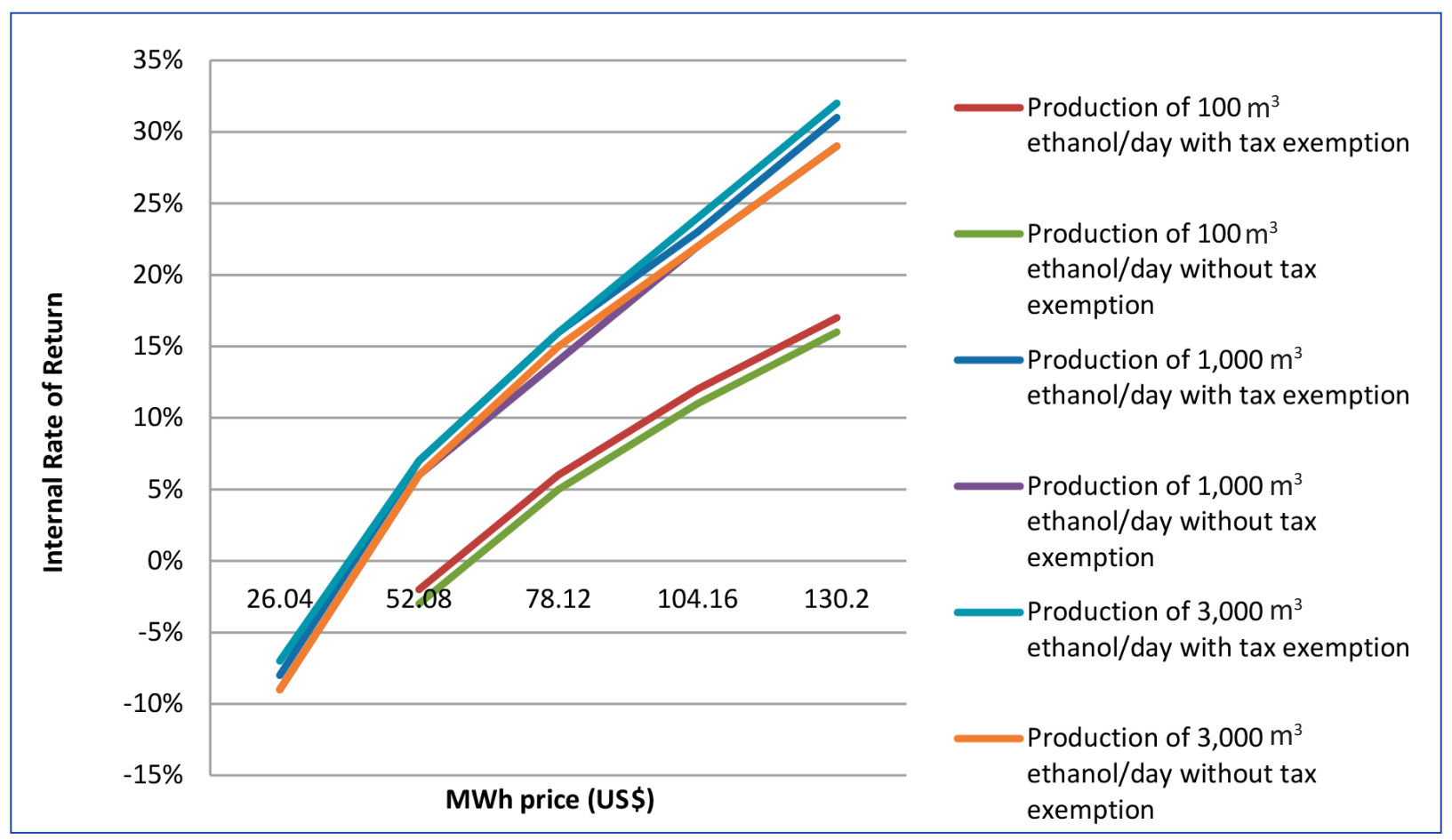

Source: Elaborated by the authors.

It can be observed that both Table 4 and Graph 1 corroborate the finding that the higher the ethanol production capacity of the plant, the greater the economic attractiveness of the sale of electricity from vinasse. In this sense, according to the method and economic scenario described in this research, plants with a production of 1,000 $\mathrm{m}^{3}$ and 3,000 $\mathrm{m}^{3}$ ethanol/day present up-close and attractive values of IRR for investment at a price of US\$ 78.12/MWh; for plants with production of $100 \mathrm{~m}^{3}$ ethanol/day, investment feasibility occurs at a price of US\$104.16/MWh.

In addition, the higher the market MWh price, the greater the enterprise's IRR. This study has also found that for plants with a capacity of 3,000 $\mathrm{m}^{3}$ ethanol/day, investment becomes feasible from US\$ 59.98/MWh with tax exemptions, and from US\$63.77/MWh without tax exemptions. For plants producing 1,000 $\mathrm{m}^{3}$ ethanol/day, with or without tax exemptions, investment feasibility occurs at US\$61.00/MWh and US\$64.85/MWh, respectively. In turn, for a plant with a production capacity of $100 \mathrm{~m}^{3} /$ day, with or without tax exemptions, investment feasibility occurs at US\$95.45/MWh and US\$101.47/MWh, respectively.

\section{Analysis of the net present value}

Table 5 and Graph 2 present the NPV for medium and large-sized plants producing 100, 1,000 and 3,000 $\mathrm{m}^{3}$ ethanol/day, for a price range from US\$26.04 to US\$130.20/MWh, with scenarios with or without tax exemptions, and with a tax burden of $5.93 \%$ on gross revenue from electricity sales. 
Table 5

Net Present Value of Electricity Sales from Vinasse

\begin{tabular}{|c|c|c|c|c|c|c|}
\hline \multirow{2}{*}{$\begin{array}{l}\text { MWh price } \\
\text { (US\$) }\end{array}$} & \multicolumn{2}{|c|}{$\begin{array}{c}\text { Production of } 100 \mathrm{~m}^{3} \text { ethanol/ } \\
\text { day }\end{array}$} & \multicolumn{2}{|c|}{$\begin{array}{c}\text { Production of } 1,000 \mathrm{~m}^{3} \\
\text { ethanol/day }\end{array}$} & \multicolumn{2}{|c|}{$\begin{array}{c}\text { Production of } 3,000 \mathrm{~m}^{3} \\
\text { ethanol/day }\end{array}$} \\
\hline & $\begin{array}{l}\text { NPV with tax } \\
\text { exemption } \\
\text { (US\$) }\end{array}$ & $\begin{array}{l}\text { NPV without } \\
\text { tax exemption } \\
\text { (US\$) }\end{array}$ & $\begin{array}{l}\text { NPV with tax } \\
\text { exemption } \\
\text { (US\$) }\end{array}$ & $\begin{array}{l}\text { NPV without } \\
\text { tax exemption } \\
\text { (US\$) }\end{array}$ & $\begin{array}{l}\text { NPV with tax } \\
\text { exemption } \\
\text { (US\$) }\end{array}$ & $\begin{array}{l}\text { NPV without } \\
\text { tax exemption } \\
\text { (US\$) }\end{array}$ \\
\hline 26.04 & $-695,904.07$ & $-711,575.55$ & $-5,505,378.58$ & $-5,751,513.52$ & $-16,311,336.08$ & $-17,062,515.21$ \\
\hline 52.08 & $-434,810.81$ & $-465,776.47$ & $-1,404,667.65$ & $-1,891,011.97$ & $-3,796,377.81$ & $-5,280,651.86$ \\
\hline 78.125 & $-173,717.55$ & $-220,166.04$ & $2,696,043.28$ & $1,966,526.81$ & $8,718,580.46$ & $6,492,169.38$ \\
\hline 104.16 & $87,375.72$ & $25,444.39$ & $6,796,754.21$ & $5,824,065.58$ & $21,233,538.72$ & $18,264,990.62$ \\
\hline 130.20 & $348,468.98$ & $271,054.83$ & $10,897,465.15$ & $9,681,604.36$ & $33,748,496.99$ & $30,037,811.86$ \\
\hline
\end{tabular}

Source: Elaborated by the authors.

Graph 2

Net Present Value of Electricity Sales from Vinasse

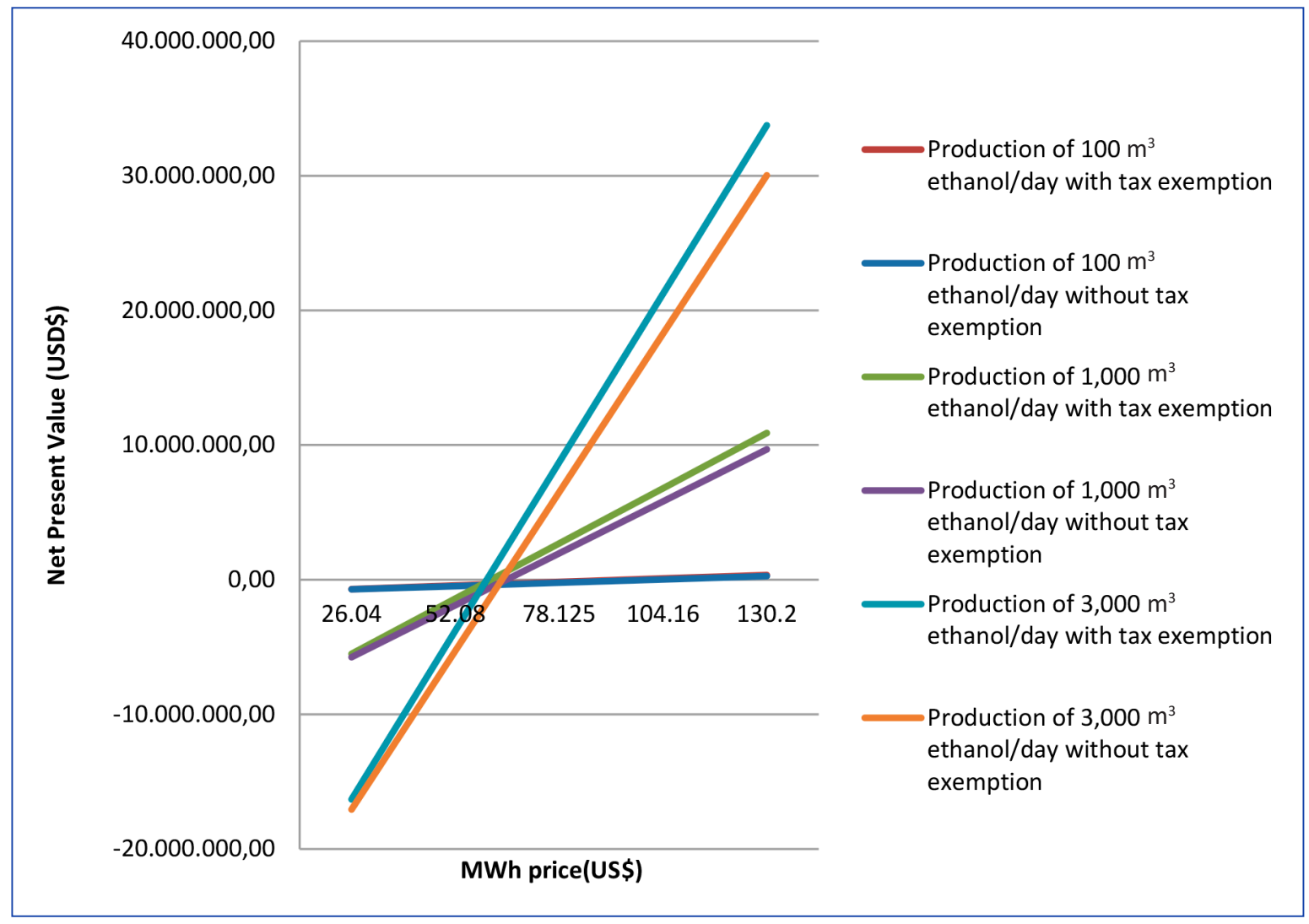

Source: Elaborated by the authors.

In the economic scenario used in this research, both Table 5 and Graph 2 show that the production capacity of ethanol, and consequently of vinasse, determine NPV attractiveness regarding electricity generation from this residue. Therefore, according to this method, a plant producing $3,000 \mathrm{~m}^{3}$ ethanol/day is more profitable than plants producing $1,000 \mathrm{~m}^{3}$ ethanol/day, which, in turn, are more attractive than plants with a production of $100 \mathrm{~m}^{3}$ ethanol/day. 
Since the NPV method is more appropriate for determining the most attractive investment, it can be stated, according to Table 5 and Graph 2, that the higher the plant production capacity, the greater its NPV. Therefore, in this study there is greater feasibility for plants producing $3,000 \mathrm{~m}^{3}, 1,000 \mathrm{~m}^{3}$ and $100 \mathrm{~m}^{3}$ ethanol/day, in this order, with or without tax exemptions.

\section{Discounted payback analysis}

The discounted payback period (20-year time horizon) for the ethanol production range considered in this study is displayed in Table 6 and Graph 3.

Table 6

Discounted Payback Period for Electricity Sales from Vinasse

\begin{tabular}{c|cccccc}
\hline & \multicolumn{2}{c}{$\begin{array}{c}\text { Production of } 100 \mathrm{~m}^{3} \\
\text { ethanol/day }\end{array}$} & \multicolumn{2}{c}{$\begin{array}{c}\text { Production of } 1,000 \mathrm{~m}^{3} \\
\text { ethanol/day }\end{array}$} & \multicolumn{2}{c}{$\begin{array}{c}\text { Production of } 3,000 \mathrm{~m}^{3} \\
\text { ethanol/day }\end{array}$} \\
\hline $\begin{array}{c}\text { MWh price } \\
\text { (US\$) }\end{array}$ & $\begin{array}{c}\text { Discounted } \\
\text { payback } \\
\text { with tax } \\
\text { exemption } \\
\text { (years) }\end{array}$ & $\begin{array}{c}\text { Discounted } \\
\text { payback } \\
\text { without tax } \\
\text { exemption } \\
\text { (years) }\end{array}$ & $\begin{array}{c}\text { Discounted } \\
\text { payback } \\
\text { with tax } \\
\text { exemption } \\
\text { (years) }\end{array}$ & $\begin{array}{c}\text { Discounted } \\
\text { payback } \\
\text { without tax } \\
\text { exemption } \\
\text { (years) }\end{array}$ & $\begin{array}{c}\text { Discounted } \\
\text { payback } \\
\text { with tax } \\
\text { exemption } \\
\text { (years) }\end{array}$ & $\begin{array}{c}\text { Discounted } \\
\text { payback } \\
\text { without tax } \\
\text { exemption } \\
\text { (years) }\end{array}$ \\
\hline 26.04 & -1040.68 & -721.83 & 290.01 & 377.01 & 272.03 & 349.7 \\
\hline 52.08 & 131.33 & 155.44 & 45.14 & 51.98 & 43.41 & 50.01 \\
78.125 & 49.66 & 57.13 & 15.87 & 19.03 & 15.04 & 18.12 \\
104.16 & 24.92 & 29.09 & 4.49 & 6.51 & 3.96 & 5.93 \\
\hline 130.20 & 12.96 & 15.81 & -1.56 & -0.08 & -1.95 & -0.51 \\
\hline
\end{tabular}

Source: Elaborated by the authors.

\section{Graph 3}

\section{Discounted Payback Period for Electricity Sales from Vinasse}

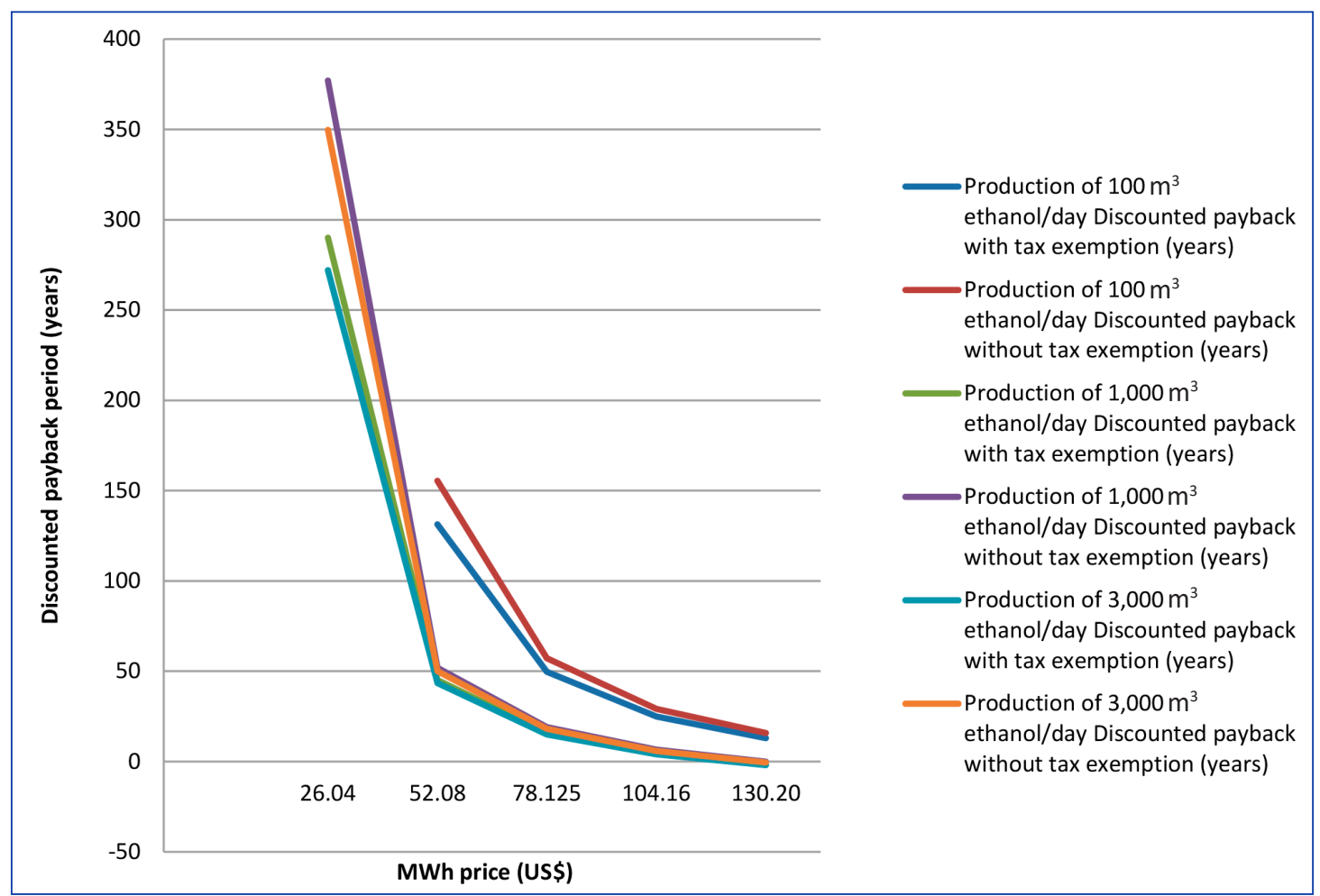

Source: Elaborated by the authors. 
The difference in the discounted payback period in relation to the plant production capacity and the MWh price can be observed in Table 6 and Graph 3, where the higher the plant production capacity and MWh price, the shorter the discounted payback period.

\section{DISCUSSION OF THE RESULTS}

Since vinasse is the most harmful byproduct of ethanol production, with high volume and polluting capacity, it is necessary to discuss its potential uses in order to find solutions to overcome this serious environmental issue. These days, based on the legislation in force, raw vinasse is used for the fertilization and irrigation of sugarcane fields near ethanol producing plants, whether autonomous or attached. However, vinasse energy potential is being wasted, since its high organic content is not being used for biogas production, diesel replacement or electricity generation via anaerobic digestion.

Moreover, the anaerobic digestion process does not remove vinasse's fertigation properties, which is in line with the environmental, economic, energy and social interests of the sugarcane-based energy sector.

Regarding the use of vinasse specifically for electricity generation, it is relevant to hydropower support, production decentralization, and the consequent security in the National Electric System, as advocated by Dantas Filho and Parente (2010), as well as environmental aspects, such as in GHG emission reduction, as addressed by the National Policy on Climate Change, the Paris Agreement, LCT and the normalization of COD and pH levels, as affirmed by Moraes, Junqueira, Pavanello et al. (2014).

However, the financial analysis carried out in this study has verified the importance of the MWh price and the scale capacity for the economic feasibility of electricity sales from vinasse. The already established sugarcane-based energy plants, faced with a crisis in this sector, have postponed or canceled projects to increase production capacity. In this sense, the MWh price is currently the economic dimension that contributes decisively to the economic feasibility of electricity generation from vinasse.

These results are in line with the Castro and Dantas (2008) study, which quantitatively demonstrates the need for the Brazilian Electricity Regulatory Agency to make exclusive electricity auctions for biomass, where the MWh price would be consistent with the cost structure of biomass thermoelectric power plants, where vinasse could be considered a resource for electricity purposes. The socioenvironmental benefits of biomass have not being priced into the current auction models of the Regulated Contracting Environment, since in RCE auctions from 2005 to 2014 the average price reached, according to Brazilian Electricity Regulatory Agency (ANEEL, 2016), was US\$35.87/MWh, contemplating wind power plants and small hydropower plants, consequently marginalizing other models, such as solar and biomass energy production.

The feasible MWh price for vinasse thermoelectric plants is between US\$ 63.77/MWh and US\$101.47/MWh as shown in Table 6. Thus, even with scale production capacity and tax exemption policies, vinasse thermoelectric power plants are not feasible at the current prices charged in the RCE electricity auctions.

Table 7

Cutoff Price for Economic Feasibility of Vinasse Thermoelectric Power Plants as a Function of Plant Production Capacity

\begin{tabular}{ccc}
\hline $\begin{array}{c}\text { Plant production } \\
\text { capacity }\end{array}$ & $\begin{array}{c}\text { Scenario with } \\
\text { tax exemption }\end{array}$ & $\begin{array}{c}\text { Scenario without } \\
\text { tax exemption }\end{array}$ \\
\hline $100 \mathrm{~m}^{3}$ ethanol/day & US\$95.45/MWh & US\$101.47/MWh \\
$1,000 \mathrm{~m}^{3}$ ethanol/day & US\$61.00/MWh & US\$64.85/MWh \\
$3,000 \mathrm{~m}^{3}$ ethanol/day & US\$59.98/MWh & US\$63.77/MWh \\
\hline
\end{tabular}

Source: Elaborated by the authors. 


\section{Graph 4}

\section{Cutoff Price for Economic Feasibility of Vinasse Thermoelectric Power Plants as a Function of Plant Production Capacity}

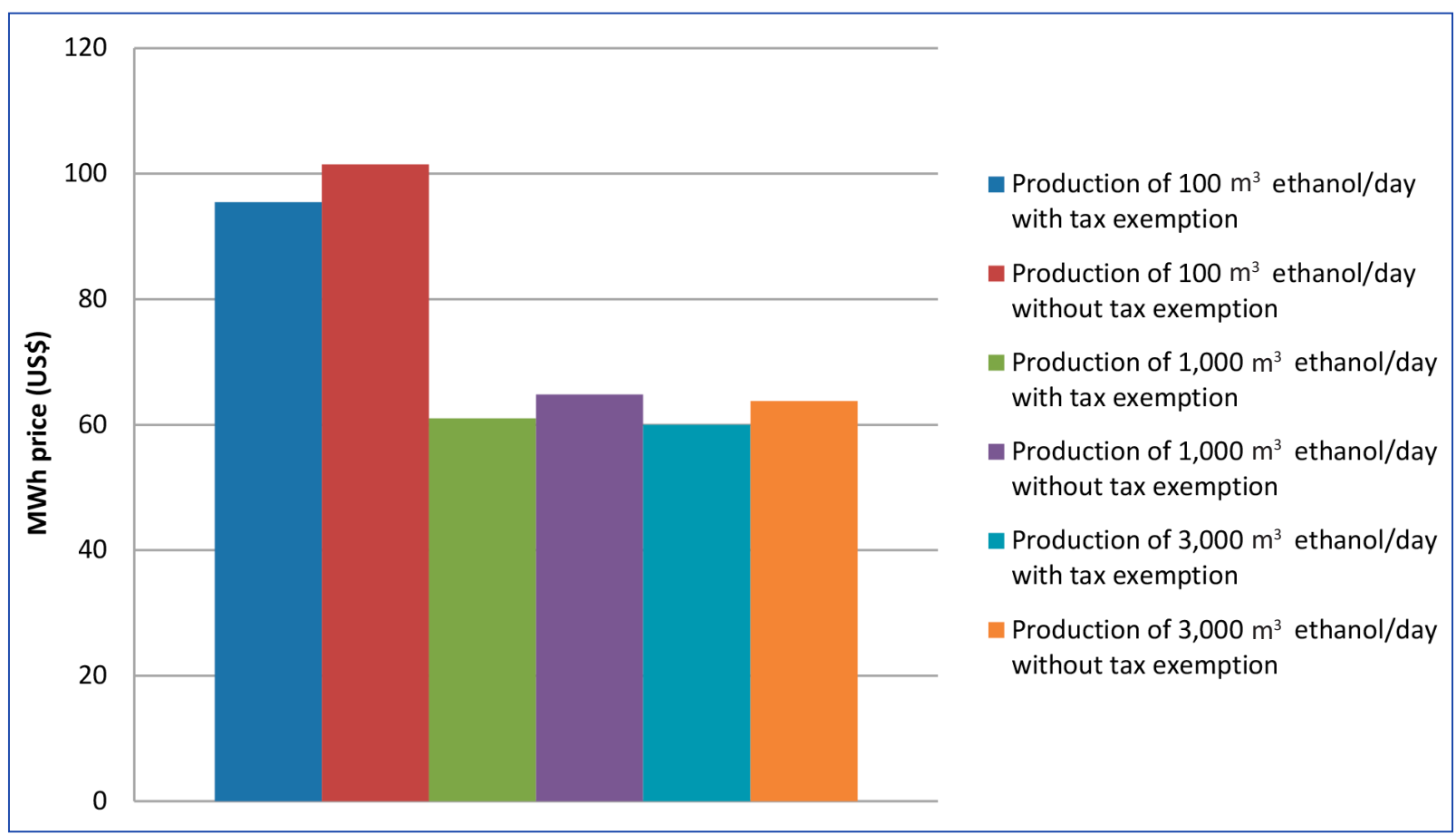

Source: Elaborated by the authors.

The resumption of exclusive auctions for biomass in the RCE is also important to give long-term economic and financial sustainability to the entrepreneur, via cash flow that allows the investment to be paid, remunerating not only the entrepreneur, but also the investment made by financial institutions, which are mostly development banks. In the free contracting environment, although the MWh price is more attractive, there is both greater volatility and shorter contract periods when compared to the regulated contracting environment; in this sense, it presents price variation risks and contracts that are not sufficient to make an enterprise viable.

Consequently, it is not an adequate parameter to perform a feasibility analysis, which reinforces the importance of RCE auctions in the promotion of new electricity enterprises in line with economic development, social promotion and environmental preservation. 


\section{CONCLUSION AND POLICY IMPLICATIONS}

Electricity is a fundamental requirement for a nation's economic and social development. In this sense, having an electric matrix that supports economic growth and social well-being in harmony with environmental preservation, and is close to consumption centers is paramount as a competitive advantage for nations.

This sector, besides producing ethanol and sugar, contributes substantially to the generation of electricity, which is clean, renewable and distributed geographically. Faced with a cost crisis in the national electricity sector, the reuse of residues for electricity generation may contribute to not only mitigating this crisis, but also reducing greenhouse gas emissions and losses in electricity transmission and distribution.

In short, electricity generation from vinasse may contribute to the following: a reduction of the environmental impacts caused by this residue; an increase in local electricity generation; a decrease in electricity loss from the transmission process; the expansion or creation of a new market for bioelectricity trade via electricity auctions held by the Brazilian Electricity Regulatory Agency (AGÊNCIA NACIONAL DE ENERGIA ELÉTRICA - ANEEL); the potential replacement of straw and bagasse for electricity generation, with a consequent increase in the production of second generation ethanol from the availability of these residues.

Therefore, a national change in electricity policy based on the elaboration and execution of exclusive electricity auctions for biomass is fundamental to the economic, social and environmental valorization of this energy matrix, as is a change in the strategic vision of our national energy policy, in which biomass does not compete with other renewable sources such as wind and photovoltaic energy, but instead complements large hydropower plants.

\section{ACKNOWLEDGMENTS}

The authors wish to thank the National Council for Scientific and Technological Development (CNPq) for the research stimulated by process no. 134.193/20.156. 


\section{REFERENCES}

AGÊNCIA NACIONAL DE ENERGIA ELÉTRICA - ANEEL. Resumo do resultado dos leilões de geração no ACR de 2005 a 2016. Brasília: ANEEL, 2016.

AGÊNCIA NACIONAL DO PETRÓLEO, GÁS NATURAL E BIOCOMBUSTÍVEIS - ANP. Dados estatísticos. Brasília, DF: ANP, 2017.

ARAUJO, G. J. F. Análise energética, ambiental, e econômica de biodigestores de circulação interna e concentradores de vinhaça para geração de eletricidade, fertilizantes e créditos de carbono em diferentes cenários econômicos. 2017. Master Thesis (Master Degree in Business Administration) - Faculdade de Economia, Administração e Contabilidade de Ribeirão Preto, Universidade de São Paulo, Ribeirão Preto, 2017.

ARAUJO, G. J. F.; OLIVEIRA, S. V. W. B.; OLIVEIRA, M. M. B. Economic Analysis of Internal Circulation Biodigesters and Vinasse Concentrators for the Generation of Electricity, Fertilizers, and Carbon Credits in Various Brazilian Economic Scenarios. Bioenergy Research, v. 12, p. 1164-1186, 2019.

BERNAL, A. P. et al. Vinasse biogas for energy generation in Brazil: An assessment of economic feasibility, energy potential and avoided $\mathrm{CO}_{2}$ emissions. Journal of cleaner production, v. 151, p. 260-271, 2017.

BRASIL. Lei no 12.187, de 29 de dezembro de 2009. Institui a Política Nacional sobre Mudança do Clima - PNMC e dá outras providências. Diário Oficial da União, Brasília, DF, 30 dez. 2009.

BRASIL. Lei no 13.971, de 27 de dezembro de 2019. Institui o Plano Plurianual da União para o período de2020 a 2023. Diário Oficial da União, Brasília, DF, 30 dez. 2019.

BUNDHOO, Z. M. A.; MAUTHOOR, S.; MOHEE, R. Potential of biogas production from biomass and waste materials in the Small Island Developing State of Mauritius. Renewable and Sustainable Energy reviews, v. 56, p. 1087-1100, 2016.

CÂMARA DE COMERCIALIZAÇÃO DE ENERGIA ELÉTRICA - CCEE. Histórico de preços semanais. São Paulo: CCEE: 2017.

CASTRO, N. J.; DANTAS, G. A. A Conexão da Bioeletricidade à Rede: Quem Paga?. Rio de Janeiro: Grupo de Estudos do Setor Elétrico, 2008.

CHRISTOFOLETTI, C. A. et al. Sugarcane vinasse: environmental implications of its use. Waste management, v. 33 , n. 12 , p. 2752 2761, 2013.

DANTAS FILHO, P. L. Análise de custos na geração de energia com bagaço de cana-de-açúcar: um estudo de caso em quatro usinas em São Paulo. 2009. Master Thesis (Master Degree in Energy) - Energia, Universidade de São Paulo, São Paulo, 2009.

EMPRESA DE PESQUISA ENERGÉTICA - EPE. Relatório Final de 2014. Rio de Janeiro: EPE, 2014.

GOLDEMBERG, J.; LUCON, O. Energias renováveis: um futuro sustentável. Revista USP, São Paulo, n. 72, p. 6-15, 2007.

HOARAU, J. et al. Sugarcane vinasse processing: Toward a status shift from waste to valuable resource. A review. Journal of water process engineering, v. 24, p. 11-25, 2018.

INVESTING. Preço do crédito de carbono no mercado futuro. São Paulo: Investing, 2017.
KISS, B. C. K. Análise da aplicação do pensamento de ciclo de vida na gestão empresarial: estudo de casos brasileiros. 2018. Master Thesis (Professional Master Degree in Business Administration) Escola de Administração de Empresas de São Paulo, Fundação Getúlio Vargas, São Paulo, 2018.

KOYAMA, M. H. et al. Kinetics of thermophilic acidogenesis of typical Brazilian sugarcane vinasse. Energy, v. 116, p. 1097-1103, 2016.

LAZARO, L. L. B.; GREMAUD, A. P. Contribuição para o desenvolvimento sustentável dos projetos de mecanismo de desenvolvimento limpo na América Latina. Organizações e Sociedade, v. 24, n. 80 , p. 53-72, 2017.

LOPES, O. A. Avaliação de métodos avançados de geração de energia elétrica na indústria de açúcar e bioenergia. 2013. Master Thesis (Master Degree in Economy) - Escola de Economia de São Paulo, Fundação Getúlio Vargas, São Paulo, 2013.

MINISTÉRIO DE MINAS E ENERGIA - MME. Plano de expansão de energia de 10 anos. Brasília, DF: MME, 2017.

MORAES, B. et al. Anaerobic digestion of vinasse from sugarcane biorefineries in Brazil from energy, environmental, and economic perspectives: Profit or expense?. Applied Energy, v. 113, p. 825835, 2014.

MORAES, B. S.; ZAIAT, M.; BONOMI, A. Anaerobic digestion of vinasse from sugarcane ethanol production in Brazil: challenges and perspectives. Renewable and Sustainable energy reviews, v. 44, p. 888-903, 2015.

MOREIRA, P. F.; MILLIKAN, B. (Orgs.). O setor elétrico brasileiro e a sustentabilidade no século 21: oportunidades e desafios. 2. ed. Brasilia, DF: International rivers network. 2012.

MOREDA, I. L. The potential of biogas production in Uruguay. Renewable and Sustainable Energy Reviews, v. 54, p. 1580-1591, 2016.

MORI-CLEMENT, Y.; BEDNAR-FRIEDL, B. Do clean development mechanism projects generate local employment? Testing for sectoral effects across Brazilian municipalities. Ecological economics, v. 157, p. 47-60, 2019.

NOGUEIRA, C. E. C. et al. Exploring possibilities of energy insertion from vinasse biogas in the energy matrix of Paraná State, Brazil. Renewable and Sustainable Energy Reviews, v. 48, p. 300-305, 2015.

OLIVEIRA, M. Vinhaça alternativa: resíduo da produção de etanol pode ser usado para produzir biodiesel. Pesquisa FAPESP, São Paulo, n. 186, p. 70-73, Aug. 2011.

OLIVEIRA, T. D.; GURGEL, A. C.; TONRY, S. International market mechanisms under the Paris Agreement: A cooperation between Brazil and Europe. Energy policy, v. 129, p. 397-409, 2019.

POVEDA, M. M. R. Análise econômica e ambiental do processamento da vinhaça com aproveitamento energético. 2015. Master Thesis (Master Degree in Economy) - Instituto de Energia e Ambiente, Universidade de São Paulo, São Paulo, 2015.

PREÇO DOS COMBUSTÍVEIS. Preço do diesel em Ribeirão Preto. Ribeirão Preto: Preço dos Combustíveis, 2017.

PROCKNOR, C. Energia elétrica a partir vinhaça. São Paulo: UNICA, 2009. 
RODRIGUES, E. Para conter rombo do setor elétrico, governo reduz preço máximo da energia. O Estado de S. Paulo, São Paulo, 25 nov. 2014.

SANTOS, F. S.; BARROS, R. M.; TIAGO FILHO, G. L. Electricity generation from biogas of anaerobic wastewater treatment plants in Brazil: an assessment of feasibility and potential. Journal of cleaner production, v. 126, p. 504-514, July 2016.

SILVA, T. A. et al. Estudo da viabilidade de implantação de um concentrador de vinhaça em uma usina produtora de etanol. In: ENCONTRO NACIONAL DE ENGENHARIA DE PRODUÇÃO, 35., Fortaleza, 2015. Anais... Fortaleza: ENEGEP, 2015. p. 1-15.

SIMÕES, C. L. N., SENA, M. E. R., CAMPOS, R. Estudo da viabilidade econômica da concentração de vinhoto através de osmose inversa.
In: ENCONTRO NACIONAL DE ENGENHARIA DE PRODUÇÃO, 24., Florianópolis, 2004. Anais... Florianópolis: ENEGEP, 2004. p. 1-8.

SUGIMOTO, L. Crise no setor energético: como entramos e como sair. Portal UNICAMP, Campinas, 28 maio 2014.

UNIÃO DAS INDÚSTRIAS DE CANA-DE-AÇÚCAR - UNICA. Revisão de estimativa da safra 2013/2014 no centro sul confirma crescimento de moagem direcionado para a produção de etanol. São Paulo: UNICA: 2014.

WILKIE, A. C. et al. Stillage characterization and anaerobic treatment of ethanol stillage from conventional and cellulosic feedstocks. Biomass and Bioenergy, v. 19, n. 2, p. 63-102, 2000. 


\section{APPENDIX}

Table A1

Harvest Data and Agro-Industrial Inputs

\begin{tabular}{lc}
\hline Harvest days & 200.00 \\
Harvest period (months) & 7.00 \\
Concentrator operation hours / harvest hours & $4,800.00$ \\
Ethanol production per day $\left(\mathrm{m}^{3}\right)$ & Data \\
Vinasse production/day $\left(\mathrm{m}^{3}\right)$ & $\mathrm{A} 1$ \\
Ethanol production/year $\left(\mathrm{m}^{3}\right)$ & $\mathrm{A} 2$ \\
Vinasse production/year $\left(\mathrm{m}^{3}\right)$ & $\mathrm{A} 3$ \\
Vinasse COD $\left(\mathrm{kg} / \mathrm{m}^{3}\right)$ & 21.00 \\
\hline
\end{tabular}

Source: Elaborated by the authors.

\section{Biodigester}

Table A2

Value of Investment in Biodigester and Motor Generator

\begin{tabular}{lccc} 
& Unit price & Unit & Total price \\
\hline IC Biodigester and desulphurizer & US\$22.13/(kgCOD/day) & A4 & A5 \\
Motor generator & US\$ $442.70 / \mathrm{kW}$ & A6 & A7 \\
\hline & Total investment & & A8
\end{tabular}

Source: Elaborated by the authors.

Table A3

Annual Operation and Cost of Maintenance of Biodigester and Motor Generator

\begin{tabular}{cccc} 
& Unit price & Unit & Total price \\
\hline Biodigester and desulphurizer & US\$0.0041/kg COD & A9 & A10 \\
Motor generator & US\$ 10.41/MWh & A11 & A12 \\
\hline Total annual operation and maintenance & & A13
\end{tabular}

Source: Elaborated by the authors.

Table A4

Data for In Natura Vinasse Logistics

\begin{tabular}{lc}
\hline \multicolumn{1}{c}{ Event } & Cost \\
\hline Monthly driver's cost plus labor and social charges on wages (US\$) & US\$1,277.31 \\
Price of diesel paid by power plant US\$/liter & US\$ 0.87 \\
Monthly depreciation and O\&M for 2318 truck and Volvo road train truck (US\$) & US\$1,562.50 \\
\hline
\end{tabular}

Source: Elaborated by the authors. 


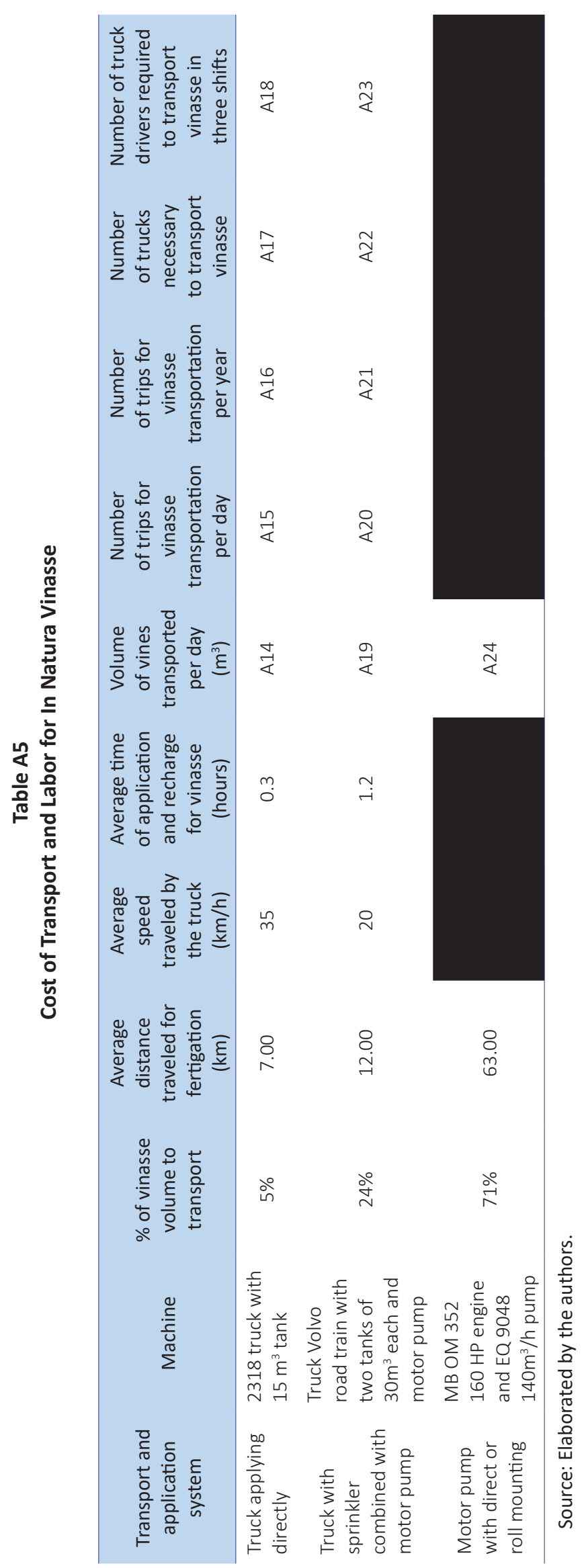


Table A6

Costs for In Natura Vinasse Logistics

\begin{tabular}{|c|c|}
\hline Monthly driver's cost plus labor and social charges on wages (US\$) & A25 \\
\hline $\begin{array}{l}\text { Fuel consumption per harvest - } 2318 \text { truck, Volvo road train truck and MB OM } 352 \text { engine and EQ } 9048 \\
\text { pump (liters) }\end{array}$ & A26 \\
\hline $\begin{array}{l}\text { Cost of fuel consumption per harvest - } 2318 \text { truck, Volvo road train truck and MB OM } 352 \text { engine and } \\
\text { EQ } 9048 \text { pump (US\$) }\end{array}$ & A27 \\
\hline Depreciation cost per harvest from the 2328 and Volvo road train truck fleet (US\$) & A28 \\
\hline Total & A29 \\
\hline
\end{tabular}

Source: Elaborated by the authors.

Table A7

Savings from Absence of Fines

Savings from absence of fines US\$ 471.35

Source: Elaborated by the authors.

Table A8

Summary of Financial Data

\begin{tabular}{ll}
\hline Life Cycle (years) & 20 \\
Price of $\mathrm{MWh}$ & US\$ 26.04, US\$ 52.08, US\$ 78.125, US\$ 104.16 and US\$ 130.20 \\
Price of tCO 2 eq & US\$ 18.72 \\
Discount rate & $10.00 \%$
\end{tabular}

Source: Elaborated by the authors.

Table A9

Cash Flow

\begin{tabular}{|c|c|c|c|c|c|}
\hline Revenue & Unit & Quantity & Year 1 & Year 2 & (...) Year 20 \\
\hline Sale of electricity (RCE) & MWh/year & $\mathrm{A} 30$ & A31 & A31 & A31 \\
\hline Sale of carbon credit (CDM) & $\mathrm{tCO}_{2} \mathrm{eq} /$ year & A32 & A33 & A33 & A33 \\
\hline \multirow[t]{2}{*}{ Savings from absence of fines } & $1 /$ year & US\$ 471.35 & US\$ 471.35 & US\$ 471.35 & US\$ 471.35 \\
\hline & & Total revenue & A34 & A34 & A34 \\
\hline Expenses & Unit & Quantity & Year 1 & Year 2 & (...) Year 20 \\
\hline O\&M of biodigester and desulphurizer & US\$/kg COD & A9 & A10 & A10 & A10 \\
\hline O\&M of motor generator & US\$/MWh & A11 & A12 & A12 & $\mathrm{A} 12$ \\
\hline \multirow[t]{3}{*}{$\begin{array}{l}\text { Taxes on sales ( } 6 \%) \text {, income }(25 \%) \text { and } \\
\text { social contributions ( } 9 \%) \text { on the sale } \\
\text { of electricity }\end{array}$} & US\$ & $5.95 \%$ & A35 & A35 & A35 \\
\hline & & Total expenses & A36 & A36 & A36 \\
\hline & & Net Cash Flow & A37 & $\mathrm{A} 37$ & $\mathrm{~A} 37$ \\
\hline
\end{tabular}

Source: Elaborated by the authors. 


\section{EQUATIONS}

Eq A1: Ethanol production per day $\left(\mathrm{m}^{3}\right) \times 10$

Eq A2: Ethanol production per day $\left(\mathrm{m}^{3}\right) \mathrm{x}$ harvest days (200 days)

Eq A3: Eq A2 x 10

Eq A4: Eq A1 x 21 (Vinasse COD in autonomous power stations $\left(\mathrm{kg} / \mathrm{m}^{3}\right)$

Eq A5: Eq A4 x US\$ 22.13 (Price of KgCOD/day)

Eq A6: (Eq A2 $\times 6$ (Biogas volume produced per $\mathrm{m}^{3}$ of vinasse $\left.\left(\mathrm{Nm} \mathrm{3}^{\prime} \mathrm{m}^{3}\right)\right) \times(1-0.05) \times 17.765 .00$ (Biogas low heat value) / $1,000,000,000) \times 0.38$ (Thermoelectric efficiency of the engine) / 4,800 (Harvest hours in the year) $\times 1000$

Eq A7: Eq A6 x US\$ 442.70 (Kw Price)

Eq A8: Eq A5 + Eq A7

Eq A9: Eq A3 x 21 (Vinasse COD in autonomous power stations $\left(\mathrm{kg} / \mathrm{m}^{3}\right)$

Eq A10: Eq A9 x US\$ 0.0041 (Price of COD kg)

Eq A11: (Eq A6/1000) x 4,800 (Hours of operation per harvest)

Eq A12: Eq A11 x US\$ 10.41 (Price MWh)

Eq A13: Eq A10 + Eq A12

Eq A14: Eq A1 x 5\% (\% of Vinasse volume to be transported by 2318 truck)

Eq A15: Eq A14 / 15 (Volume in $\mathrm{m}^{3}$ transported by 2318 truck)

Eq A16: Eq A15 x 200 (Days of harvest in the year)

Eq A17: Eq A14/360 (Maximum volume in $\mathrm{m}^{3}$ of vinasse transported by 2318 truck on a workday in three shifts)

Eq A18: Eq A17 x 3 (work shifts)

Eq A19: Eq A1 x 24\% (\% of Vinasse volume to be transported by Volvo road train truck)

Eq A20: Eq A10 / 60 (Volume in $\mathrm{m}^{3}$ transported by Volvo road train truck)

Eq A21: Eq A20 x 200 (Days of harvest in the year)

Eq A22: Eq A19 / 600 (maximum volume in $\mathrm{m}^{3}$ of vinasse transported by Volvo road train truck on a workday in three shifts)

Eq A23: Eq A22 × 3 (Work shifts)

Eq A24: Eq A1 x 71\% (\% of Vinasse volume to be transported by MB OM 352160 CV engine and EQ 9048 pump)

Eq A25: US\$ 1,277.31 (Monthly driver's cost plus labor and social charges on wages) x (Eq A18 + Eq A23) x 7 (Harvest period in months)

Eq A26: ((Eq A24/7.5 (Vinasse volume pumped in $\mathrm{m}^{3}$ per one liter of diesel consumed in MB OM $352160 \mathrm{CV}$ engine and EQ 9048 pump $\left.\left(\mathrm{m}^{3}\right)\right)+($ Eq A15 $\times 6.36$ (diesel volume consumed by 2318 truck on one trip for transporting concentrated vinasse (liters/trip)) + (Eq A20 18.46 (Volume of diesel consumed by the Volvo road train truck on one trip for transporting concentrated vinasse (liters/trip))) + (Eq A19/7.5 (Volume of vinasse pumped in $\mathrm{m}^{3}$ per one liter of diesel consumed by MB OM 352160 CV engine and EQ 9048 pump $\left.\left(\mathrm{m}^{3}\right)\right)$ x (200 (Days of harvest))

Eq A27: Eq A26 x US\$ 0.87 (Price of diesel paid by the power station US\$/liter)

Eq A28: (US\$ 1,562.50 (Depreciation and monthly O\&M for 2318 truck and Volvo road train truck) x (Eq A17 + Eq A22)) 7 (Harvest period in months)

Eq A29: Eq A25 + Eq A26 + Eq A27 + Eq A28 
Eq A30: (Eq A2 x 6 (Biogas volume produced per $\mathrm{m}^{3}$ of vinasse $\left.\left(\mathrm{Nm}^{3} / \mathrm{m}^{3}\right)\right) \times(1-0.05) \times 17.765 .00$ (Biogas low heat value) / $1,000,000,000) \times 0.38$ (Thermoelectric efficiency of the engine) $-(4,800.00$ (Harvest hours in the year) $\times 200$ (Harvest days in the year) $x($ Eq A1 /4000)/1000))

Eq A31: Eq A30 x (US\$ US\$ 26.04, US\$ 52.08, US\$ 78.125, US\$ 104.16 and US\$ 130.20 (MWh price))

Eq A32: (Eq A2 x 6 (Biogas volume produced per $\mathrm{m}^{3}$ of vinasse $\left.\left(\mathrm{Nm}^{3} / \mathrm{m}^{3}\right)\right) \times(1-0.05) \times 17.765 .00$ (Biogas low heat value) / $1,000,000,000) \times 0.38$ (Thermoelectric efficiency of the engine) $\times 89.29$ ( $\mathrm{NO}_{\mathrm{x}}$ factor avoided through electricity generation $(\mathrm{g} / \mathrm{MWh}))) / 1,000,000.00) 296\left(\mathrm{CO}_{2}\right.$ equivalent to 1 ton $\left.\mathrm{NO}_{\mathrm{x}}\right)$

Eq A33: Eq A32 x US\$ 18.72 ( $\mathrm{tCO}_{2}$ eq price)

Eq A34: Eq A31 + Eq A33 + US\$ 471.35

Eq A35: Eq A31 x 5.93\% (Taxes on sales, income and social contribution on the sale of electricity)

Eq A36: Eq A10 + Eq A12 + Eq A35

Eq A37: Eq A34 - Eq A36 